\title{
The Mechanism of Action of Nitro-heterocyclic Antimicrobial Drugs. Primary Target of 1-Methyl-2-nitro-5-vinylimidazole is DNA
}

\author{
By BETH P. GOLDSTEIN, ERIK NIELSEN,* MARISA BERTI, \\ GIULIANA BOLZONI AND LUIGI G.SILVESTRI $\dagger$ \\ Direzione Laboratori di Chemioterapia, Gruppo Lepetit S.p.A., Milan, Italy
}

(Received I4 December 1976)

\begin{abstract}
SUMMARY
The antimicrobial drug I-methyl-2-nitro-5-vinylimidazole (MEV) preferentially blocked DNA synthesis, was mutagenic and induced coliphage $\lambda$ in Escherichia coli. The antibacterial effects of MEV are the consequences of repairable damage to DNA, as shown by hypersensitivity of $r e c A$ and $u v r$ strains to MEV and related drugs, stimulation by MEV of DNA turnover which was dependent on the product of the $u v r A$ gene, and the presence of cross-links in DNA from MEV-treated bacteria.
\end{abstract}

\section{INTRODUCTION}

Although nitro-heterocyclic antimicrobial drugs have been used for a number of years (Dodd \& Stillman, 1944; Dann \& Möller, 1947), their mode of action is only now beginning to be understood. As these drugs inhibit in vitro a wide variety of enzymic reactions assayed by dye or pyridine nucleotide reduction (Paul \& Paul, 1964), they were initially thought to interfere primarily with energy generation. Thus Saeki et al. (1974) attributed the inhibition of DNA synthesis by azomycin (2-nitroimidazole) to the inhibition of ribonucleoside reductase even though they were not convinced that inhibition of this enzyme accounted for the bactericidal effect of the drug.

Other studies in which metabolically activated nitrofurans and nitroimidazoles were shown to bind to DNA (McCalla, Reuvers \& Kaiser, I970; Ings, McFadzean \& Ormerod, 1974; Tu \& McCalla, I975) and recent reports on the mutagenicity of such compounds (Yahagi et al., 1974; Voogd, Van der Stel \& Jacobs, 1974, 1975) suggest a direct effect of such drugs on DNA. In this study, we give evidence that the primary antibacterial action of I-methyl-2-nitro-5-vinylimidazole (MEV) (Cavalleri et al., I973) is inhibition of DNA replication, and we explore the mechanism of this inhibition in Escherichia coli.

\section{METHODS}

Antibiotics and chemotherapeutic agents. MEV and azomycin were synthesized by Dr B. Cavalleri (Cavalleri, Ballotta \& Lancini, 1972; Lancini \& Lazzari, I965). Ampicillin and metronidazole were purchased from Farmitalia (Milan, Italy); mitomycin C from Sigma; and nitrofurazone, nitrofurantoin, furazolidone, nitrofuraltadone, trimethoprim, nalidixic acid, tetracycline, kanamycin and neomycin from Prodotti Gianni (Milan, Italy). Rifampicin is produced by Lepetit (Milan, Italy).

\footnotetext{
* Present address: Istituto di Genetica, Università di Pavia, Pavia, Italy.

$\dagger$ Present address: Cattedra di Microbiologia, Università di Roma. Roma, Italy.
} 
Table I. Strains of E. coli KI 2 used

\begin{tabular}{|c|c|c|c|c|}
\hline $\begin{array}{l}\text { Lepetit } \\
\text { no. }\end{array}$ & $\begin{array}{c}\text { Common } \\
\text { name }\end{array}$ & $\begin{array}{l}\text { Relevant } \\
\text { genotype }\end{array}$ & Comments & Source \\
\hline $\begin{array}{l}\mathbf{L} 679 \\
\mathbf{L} 680\end{array}$ & $\begin{array}{l}594 \\
\text { c600 }\end{array}$ & $\sup E$ & $\begin{array}{l}\text { Non-suppressing } \lambda \text { indicator } \\
\text { Indicator permitting growth of } \lambda O_{29}\end{array}$ & $\begin{array}{l}\text { W. F. Dove } \\
\text { G. Sironi }\end{array}$ \\
\hline $\mathbf{L} 678$ & Ymel & tyrT & Indicator permitting growth of $\lambda S_{7}$ & W. F. Dove \\
\hline L354 & JC2926 & recAI3 & & G. Sironi \\
\hline L694 & JC2879 & his & $\mathrm{rec}^{+}$; otherwise isogenic to $\mathrm{L} 354$ & G. Sironi \\
\hline L665 & KMBL82 & uvrA & & Institut Pasteur \\
\hline $\mathrm{L} 490$ & R90I & $u v r B$ & & A. Campbell \\
\hline $\mathrm{L} 683$ & & L694 $(\lambda h)$ & & This work \\
\hline L695 & & L694 $(\lambda c 1857$ ind $)$ & & This work \\
\hline L696 & & L694 ( $\lambda$ susO29) & & This work \\
\hline L733 & & L694 ( $\lambda$ cI857ind susS7) & & This work \\
\hline L699 & & L694 thy & Trimethoprim selection (Miller, 1972) & This work \\
\hline
\end{tabular}

Bacteria and bacteriophages. All bacterial strains used were derivatives of $E$. coli $\mathrm{KI} 2$ and are described in Table r. Coliphage $\lambda$ strains were obtained from W. F. Dove; sus indicates an amber mutant.

Growth conditions. Unless otherwise indicated, experiments used bacteria growing exponentially, with aeration, in EM9 medium (Clark et al., I966) at $37^{\circ} \mathrm{C}$.

Bactericidal effect of $M E V$. At intervals, portions of cultures containing $\mathrm{MEV}$ were diluted Ioo-fold in physiological saline $[0.9 \%(\mathrm{w} / \mathrm{v}) \mathrm{NaCl}]$ and colony-forming units (c.f.u.) were counted on NB agar (containing Oxoid no. 2 nutrient broth).

Drug sensitivity. Nutrient broth containing serial twofold dilutions of a drug were inoculated with $\mathrm{IO}^{2}$ to $\mathrm{IO}^{3}$ bacteria $\mathrm{ml}^{-1}$. The minimal inhibitory concentration (m.i.c.) was taken as the lowest concentration of a drug at which there was no visible bacterial growth after approximately $20 \mathrm{~h}$ incubation without aeration at $37^{\circ} \mathrm{C}$.

Prophage $\lambda$ induction. Induction by ultraviolet (u.v.) light or by $\mathrm{MEV}$ was scored as

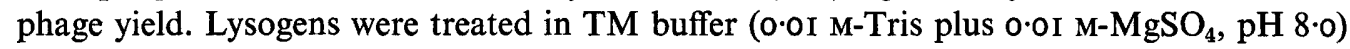
diluted roo-fold in .Tryptone broth (Difco), and incubated for $90 \mathrm{~min}$ without aeration. Chloroform was added and the phage titres of lysates were determined in soft agar (Tryptone) as described by Adams (1959).

Mutagenesis. Bacteria were grown to $E_{590}=\mathrm{I} \cdot 0$ and then incubated for $90 \mathrm{~min}$ without aeration with various concentrations of MEV. The cultures were centrifuged and concentrated ro-fold in physiological saline. Rifampicin-resistant mutants were scored by including samples of cultures in $2.5 \mathrm{ml}$ soft NB agar [0.7\% (w/v) agar] on $20 \mathrm{ml}$ normal $(\mathrm{r} .5 \%) \mathrm{NB}$ agar base, incubating at $37^{\circ} \mathrm{C}$ for $2 \mathrm{~h}$ and then overlayering with $2.5 \mathrm{ml} \mathrm{NB}$ soft agar containing I $\mathrm{mg}$ rifampicin $\mathrm{ml}^{-1}$; total c.f.u. were counted on drug-free medium. His $^{+}$revertants were scored by plating on Davis agar (Davis \& Mingioli, 1950) supplemented with all nutritional requirements, and on the same medium but without histidine. Reversion of $\lambda$ sus mutations was determined by plating the phage on appropriate permissive and non-permissive indicator strains (see Table I).

$D N A$ degradation. Method I. A very dilute culture of bacteria was prelabelled for $3 \mathrm{~h} \mathrm{in}$ medium supplemented with $0.2 \mathrm{~mm}$-deoxyadenosine (Sigma) and $\left[\right.$ methyl $\left.{ }^{3} \mathrm{H}\right]$ thymidine ( $2 \mu \mathrm{Ci} \mathrm{ml} l^{-1}$, specific activity $28 \mathrm{Ci} \mathrm{mmol}^{-1}$; The Radiochemical Centre, Amersham). The bacteria were filtered (Millipore, HAWP), resuspended and chased for $2 \mathrm{~h}$ with $\mathbf{0 . 2}$ mM-deoxyadenosine and $0.8 \mathrm{~mm}$ unlabelled thymidine. The culture was divided for MEV treatment and at intervals $0.5 \mathrm{ml}$ samples were pipetted into $0.5 \mathrm{ml}$ ice-cold $10 \%(\mathrm{w} / \mathrm{v})$ 
trichloroacetic acid (TCA). Samples were processed as described by Clark et al. (I966) and the radioactivities of $0.3 \mathrm{ml}$ samples of total TCA suspensions and of supernatant fluids were measured in Io $\mathrm{ml}$ Instagel (Packard).

Method 2. Two cultures of strain L699 (thy) were grown in parallel in medium supplemented with $0.04 \mathrm{~mm}$-thymine, except that one culture was labelled with $\left[{ }^{3} \mathrm{H}\right]$ thymidine ( $3 \mu \mathrm{Ci} \mathrm{ml}{ }^{-1}$, specific activity $28 \mathrm{Ci} \mathrm{mmol}^{-1}$ ) for $30 \mathrm{~min}$ and chased for $105 \mathrm{~min}$ before the culture was divided for MEV treatment, while the second was labelled by addition of $\left[{ }^{3} \mathrm{H}\right]$ thymidine $\left(0.3 \mu \mathrm{Ci} \mathrm{ml}^{-1}\right.$, specific activity $\left.0.75 \mathrm{Ci} \mathrm{mmol}^{-1}\right)$ during the Io min immediately preceding MEV treatment. At the time of MEV addition, excess unlabelled thymidine $(0.8 \mathrm{~mm})$ was added to both cultures which were then divided into $2 \mathrm{ml}$ portions and incubated without aeration. The reactions were stopped by adding $2 \mathrm{ml}$ ice-cold $10 \%$ TCA, and the samples were processed as above.

Properties of DNA from treated bacteria. A 31 culture was grown to $E_{590}=\mathrm{I} \cdot 3$ and divided for treatment (IO or $\mathrm{I} 5 \mathrm{~min}$ without aeration). Sodium azide was added to $0.0 \mathrm{I} \mathrm{M}$ and the bacteria were chilled, centrifuged, washed twice in DNA buffer and resuspended in $8 \mathrm{ml}$

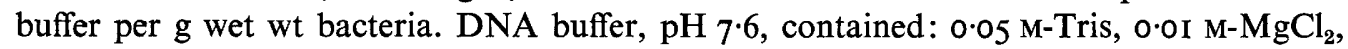
$0.1 \mathrm{M}-\mathrm{NaCl}, 10 \%(\mathrm{w} / \mathrm{v})$ sucrose, $3 \%(\mathrm{v} / \mathrm{v})$ glycerol, 0.0I M-dithiothreitol, 0.0 I M-sodium azide, and $0.02 \mathrm{M}$-spermidine. Bacteria were incubated with $2 \mathrm{mg}$ egg white lysozyme $\mathrm{ml}^{-1}$ (Sigma, grade I) for $45 \mathrm{~min}$ at $4{ }^{\circ} \mathrm{C}$ and then for 5 to Io min at $37^{\circ} \mathrm{C}$. Sarkosyl was added to $\mathrm{I} \%(\mathrm{w} / \mathrm{v})$ at $4{ }^{\circ} \mathrm{C}$ to complete lysis. DNA was extracted either by the phenol method (Saito \& Miura, I963) or by the method of Marmur (196I). Yields of DNA were calculated from the $E_{260}$, assuming a molar extinction coefficient of 6740 (Mahler \& Cordes, 1966).

DNA was denatured by heating at $95{ }^{\circ} \mathrm{C}$ for Io min in $0.1 \times \mathrm{SSC}$ buffer $(\mathrm{I} 5 \mathrm{mM}-\mathrm{NaCl}$ plus I. 5 mM-sodium citrate, $\mathrm{pH} 7 \cdot 0$ ) and was allowed to cool at room temperature. About $5 \mu \mathrm{g}$ DNA in $\mathrm{CsCl}$ solution (density $\mathrm{I} \cdot 7 \mathrm{~g} \mathrm{ml}^{-1}$; Iyer \& Szybalski, 1963) was equilibrated in a gradient established in a Spinco model $\mathrm{E}$ centrifuge at $20^{\circ} \mathrm{C}, 39400 \mathrm{rev} . \mathrm{min}^{-1}$ (I 3000g). The gradients were photographed with u.v. optics after equilibrium had been reached (approximately $22 \mathrm{~h}$ ); negatives were traced with a Joyce-Loebl recording microdensitometer.

\section{RESULTS AND DISCUSSION}

\section{Effect of $M E V$ on bacterial growth and survival}

The bactericidal effect of MEV on a strain of E. coli (L694) having normal sensitivity to MEV and structurally related drugs is shown in Fig. I. The extinction of these treated cultures increased by a factor of two or more even at the higher drug concentration $(0.33 \mathrm{mM})$ despite the strong bactericidal effect. Bacterial survival dropped to less than $\mathrm{I} \%$ in the first hour, during which time the increase in extinction was most pronounced.

The increase in extinction reflected continued protein synthesis, as measured by incorporation of $\left[{ }^{3} \mathrm{H}\right]$ phenylalanine (R. Vidal-Plana, unpublished data). On the other hand, DNA replication (measured by incorporation of $\left[{ }^{3} \mathrm{H}\right]$ thymidine into TCA-precipitable material) was completely blocked by bactericidal concentrations of the drug - within $30 \mathrm{~min}$ of adding 0.17 mM-MEV. RNA synthesis (measured by $\left[5^{-3} \mathrm{H}\right]$ uracil incorporation) was less sensitive than DNA synthesis but was more sensitive than bacterial growth (measured by increase in extinction). DNA and RNA synthesis were measured in the same cultures used for the experiment shown in Fig. I (B. Goldstein, unpublished data).

Microscopic examination of the treated cultures showed the progressive accumulation of filamentous cells. This is a characteristic consequence of treatments which preferentially block DNA replication, and hence septation (Ramareddy \& Reiter, I969; Witkin, 1974). 


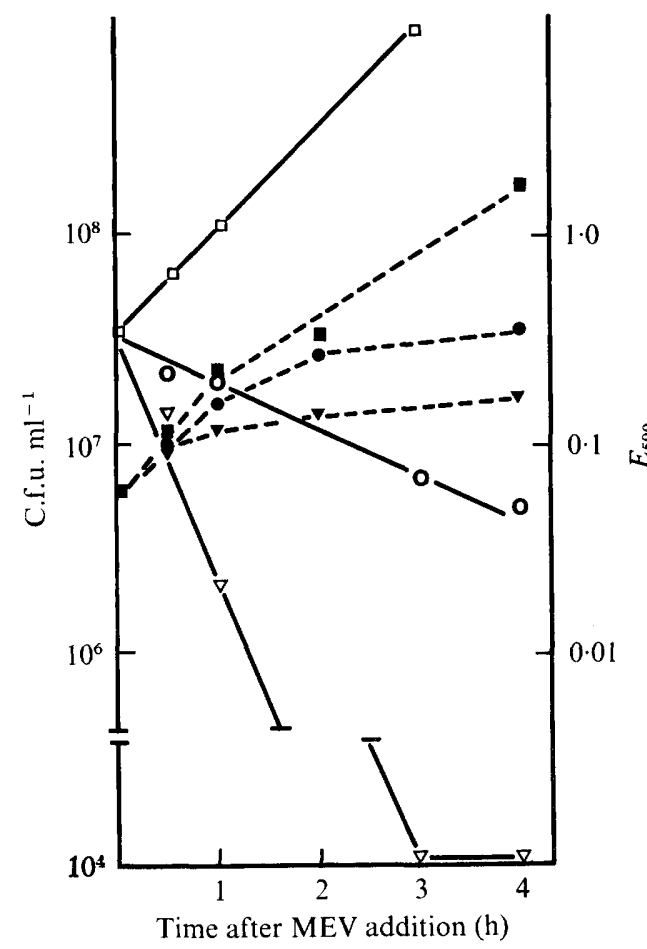

Fig. I

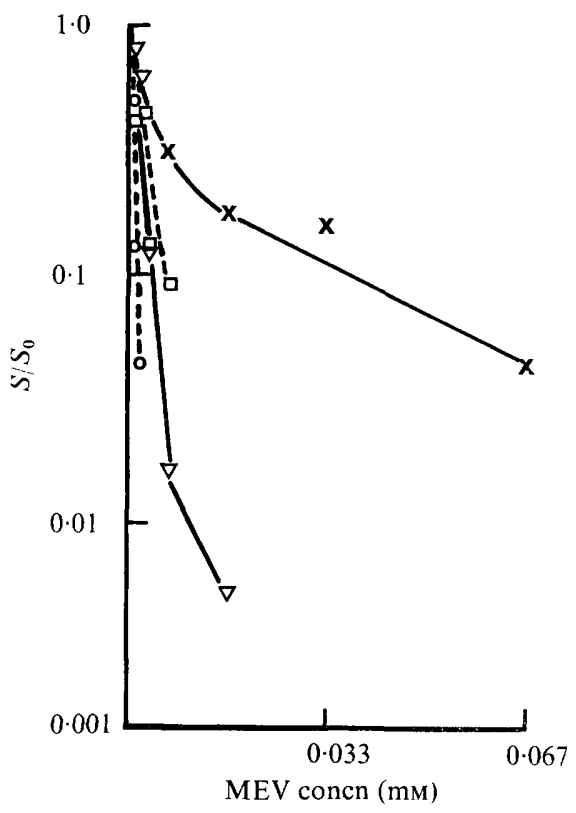

Fig. 2

Fig. I. Effect of MEV on bacterial growth and viability in E. coli. Strain L694 was exposed to MEV at $(\mathrm{mM})$ : $0(\square, \square), 0.17(\bigcirc, \bigcirc), 0.33(\nabla, \nabla)$. C.f.u. $\mathrm{ml}^{-1}(\square, \bigcirc, \nabla)$ and $E_{590}(\square, \bigcirc, \nabla)$ were determined at intervals.

Fig. 2. Sensitivities of wild-type, rec and $u v r$ strains of $E$. coli to MEV. Strains L694 $\left(\right.$ rec $\left.^{+} u v r^{+}\right)$, $\times$; L354 (recA13uvr+), $\bigcirc$; L490 $\left(\mathrm{rec}^{+} u v r B\right), \nabla$; and $\mathrm{L} 665\left(\mathrm{rec}^{+} u v r A\right), \square$; were treated with the indicated concentrations of MEV for 90 min without aeration in EM9. Data are plotted as the ratio of c.f.u. in the treated sample $(S)$ to the c.f.u. in an untreated sample of the same strain at the same time $\left(S_{0}\right)$. Untreated controls contained $\mathrm{x} \cdot 5$ to $3 \times 10^{8}$ c.f.u. $\mathrm{ml}^{-1}$ at $0 \mathrm{~min}$ and three to four times as many bacteria at $90 \mathrm{~min}$.

\section{Strains of E. coli hypersensitive to nitro-drugs}

Strains of $E$. coli which have reduced capacity to repair DNA were hypersensitive to MEV and to structurally related drugs. Thus, $\operatorname{rec} A, u v r A$ and $u v r B$ strains were sensitive to much lower MEV concentrations than was the wild-type strain (Fig. 2).

The hypersensitivity of $\operatorname{rec} A$ strains to other nitroimidazoles and nitrofurans was shown by comparing the m.i.c. with those for an isogenic $\mathrm{rec}^{+}$strain (Table 2). A similar observation for some other nitrofurans has been reported (Yahagi et al., 1974). As expected, strain L354 (recAI3) was hypersensitive to structurally unrelated drugs (mitomycin C, nalidixic acid) which interfere with DNA synthesis, but had wild-type sensitivity to the other nonnitro-drugs listed in Table 2. Among the nitro-heterocyclic compounds tested, even those which were quite ineffective against wild-type $E$. coli (for example, metronidazole, which had a m.i.c. of $4 \mathrm{mM}$ for strain L694) were much more active against the $\operatorname{rec} A$ strain. $\operatorname{rec} A$ and $u v r$ strains of Bacillus subtilis were also found to be hypersensitive to MEV (Mastromei \& Riva, personal communication).

Strains of $E$. coli lysogenic for bacteriophage $\lambda$ were also hypersensitive to MEV (unpublished observation). This is due to the fact that MEV induced the prophage (Fig. 3). 
Table 2. Hypersensitivity of a recA strain (L354) to nitro-drugs

Strain L694 is rec ${ }^{+}$, strain L354 rec A; otherwise they are isogenic.

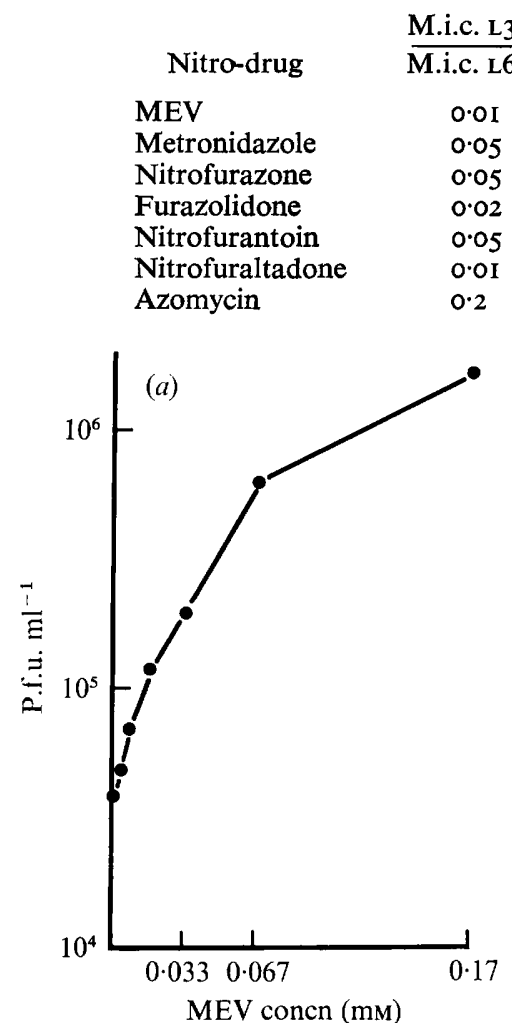

\begin{tabular}{lc} 
& M.i.c. L354 \\
\cline { 2 - 2 } Other drug & M.i.c. L694 \\
Nalidixic acid & $\mathbf{0 . 2}$ \\
Mitomycin C & 0.03 \\
Tetracycline & 0.5 \\
Ampicillin & 0.5 \\
Kanamycin & 1.0 \\
Rifampicin & 0.5 \\
Neomycin & 1.0
\end{tabular}

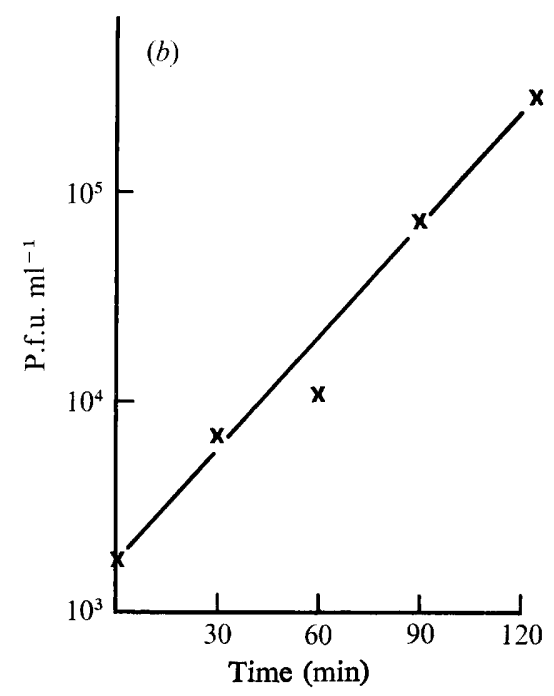

Fig. 3. Induction of prophage $\lambda$ by MEV in $E$. coli. Phage production (p.f.u. $\mathrm{ml}^{-1}$ ) by strain $\mathrm{L} 683$ is plotted as a function of (a) MEV concentration (treatment for $15 \mathrm{~min}$ ) and $(b)$ time of exposure to $0.07 \mathrm{mM}-\mathrm{MEV}$. $E_{590}$ during treatment was 0.2 .

Induction occurred after relatively mild treatment which had no immediate bactericidal effect. Phage yields were comparable to those obtained from the same cultures by u.v. induction. MEV did not induce $\lambda$ c1857ind, which is refractory to u.v. induction, in the otherwise isogenic lysogen $\mathbf{L} 695$.

The nitrofurans NFT (Endo et al., 1963), nitrofurazone and nitrofurantoin (Kirby, Ruff $\&$ Goldthwait, 1972) have also been reported to induce $\lambda$.

\section{Mutagenicity of $M E V$}

We observed an increased frequency of rifampicin-resistant mutants and of His ${ }^{+}$revertants among survivors of strain L694 exposed to MEV (Fig. 4). This was not the result of selection by MEV of pre-existant mutants, as shown by the following observations. (i) When treated bacteria were directly plated on $0.1 \mathrm{mg}$ rifampicin $\mathrm{ml}^{-1}$, the apparent frequencies of resistant mutants were similar to that of the control culture. This suggests that the majority of rifampicin-resistant mutants in the treated cultures arose during treatment. Delayed selection permits segregation of the predominantly recessive rifampicin-resistant mutations or dilution of pre-existing pools of sensitive RNA polymerase (Austin et al., 1971). (ii) In 


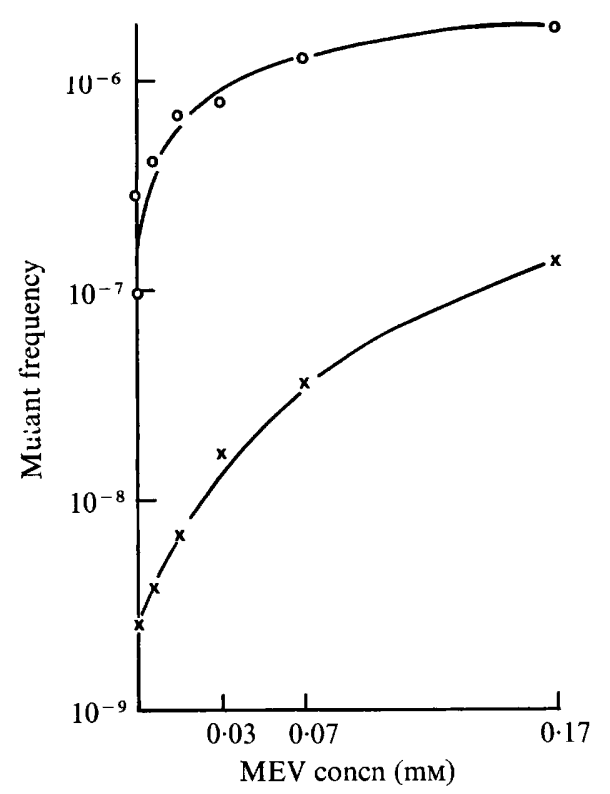

Fig. 4. Mutagenicity of MEV. Rifampicin-resistant $(O)$ and histidine-independent $(x)$ mutants of $E$. coli were scored as described in Methods.

a reconstruction experiment, spontaneously occurring $\mathrm{His}^{+}$and rifampicin-resistant mutants (from the untreated control) were grown in parallel to strain L694. A culture consisting of $98 \%$ strain $\mathrm{L} 694$ and $\mathrm{I} \%$ of each mutant was then treated as in the original mutagenesis experiment. Frequencies of $\mathrm{His}^{+}$and of rifampicin-resistant mutants in the treated cultures did not vary significantly from $\mathrm{I} \%$.

We failed to detect MEV-stimulated reversion of two different amber mutations of bacteriophage $\lambda$ in a variety of experiments. The $\mathrm{O}^{+}$revertants of $\lambda$ susO2g were scored: (i) in bursts of strain L696 after MEV induction; (ii) in bursts from a lytic cycle (strain L694 infected with $\mathrm{O}_{29}$ and treated with MEV); (iii) among lysogens (strain L696) surviving MEV treatment. In this last experiment, His ${ }^{+}$bacterial revertants were scored as a positive control for the effectiveness of the drug. The $S^{+}$revertants of $\lambda S 7$ ind were scored in lysates, obtained by heat induction, of control and MEV-treated cultures of strain L733; again, $\mathrm{His}^{+}$revertants, scored immediately after $\mathrm{MEV}$ treatment (before prophage induction), served as a positive control.

Lack of reversion of these amber mutations might indicate a preference of MEV for guanine:cytosine base pairs. MEV probably does not predominantly cause frameshifts or deletions because it efficiently induced rifampicin resistance (such mutations in RNA polymerase should be lethal).

MEV is also fungicidal (V. Arioli \& M. Berti, unpublished observations) and mutagenic activity has been detected in yeast (G. Magni, personal communication). Mutagenic activity of a nitrofuran (nitrofurazone) in $E$. coli had been observed by Zampieri \& Greenberg (1964). More recently, several nitrofurans (Yahagi et al., 1974) and some nitroimidazoles (Voogd et al., 1974, 1975) were shown to be mutagenic in bacteria. 


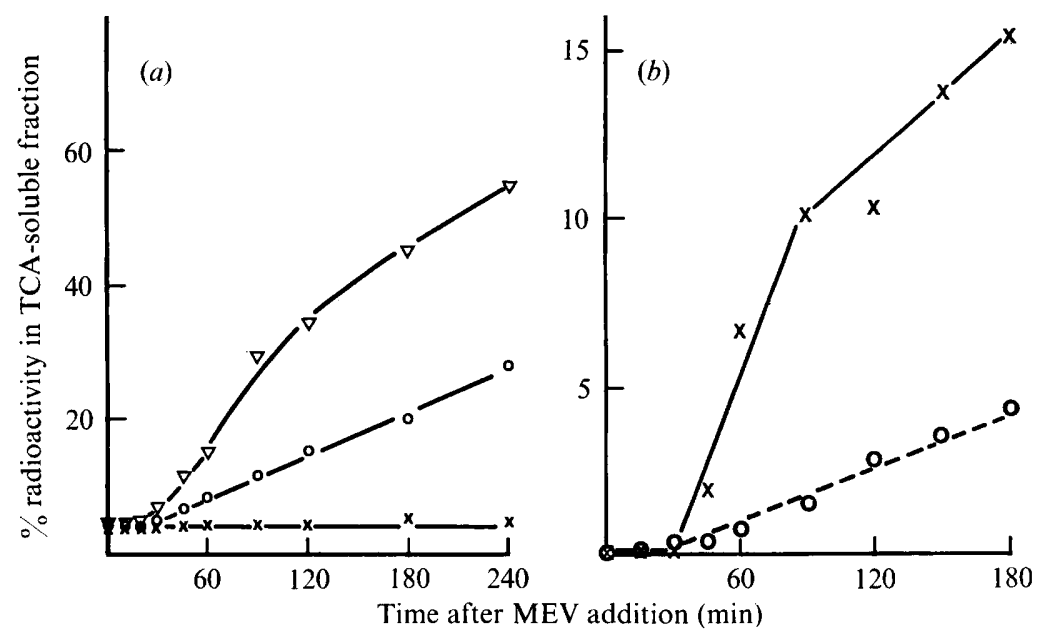

Fig. 5. Induction of DNA degradation by MEV in E. coli. Bacteria were prelabelled with [ $\left.{ }^{3} \mathrm{H}\right]$ thymidine and chased with unlabelled thymidine. (a) Strain L694 treated with $0.17(O)$ or $0.33(\nabla)$ mM-MEV; $\times$, untreated control. (b) Strains L694 (wild type, $\times$ ) and L665 (uvrA, O) were treated with $0.17 \mathrm{mM}-\mathrm{MEV}$. Density of the cultures at the time of drug addition (time 0 ) was the same as in Fig. I.

\section{Induction of DNA turnover by $M E V$}

While we had observed a precocious block by MEV of the cumulative exponential synthesis of DNA, the rate of DNA synthesis (measured by incorporation of $\left[{ }^{3} \mathrm{H}\right]$ thymidine in 2 min pulses) declined only gradually after MEV addition (unpublished observation). This suggested that some DNA turnover might be occurring.

When bacteria whose DNA had been prelabelled with $\left[{ }^{3} \mathrm{H}\right]$ thymidine (method I) were exposed to 0.17 or $0.33 \mathrm{mM}-\mathrm{MEV}$, radioactivity appeared in the cold TCA-soluble fraction at about 30 and 20 min, respectively, after drug addition (Fig. $5 a$ ). After $4 \mathrm{~h}$ exposure to $0.33 \mathrm{mM}-\mathrm{MEV}, 50 \%$ of the DNA was solubilized, and $30 \%$ on similar exposure to $0.17 \mathrm{mM}$ MEV. Brief MEV treatment, which caused little or no killing, also induced measurable DNA degradation; for example, after exposure to $0.17 \mathrm{mM}-\mathrm{MEV}$ for $5 \mathrm{~min}$, wild-type E. coli degraded $15 \%$ of its DNA over the ensuing $3 \mathrm{~h}$ (R. Vidal-Plana, unpublished observation. The DNA of a $u v r A$ strain was quite stable to MEV treatment (Fig. $5 b$ ). This is consistent with MEV-induced DNA turnover being dependent on the excisionrepair endonuclease (Braun \& Grossman, 1974).

The effects of MEV described above (preferential block of replication, filament formation, prophage induction and DNA turnover at sub-bactericidal concentrations, and mutagenesis) suggest that the essential target of this drug is DNA synthesis. The data are consistent with one of two primary modes of drug action: inhibition of progression of the replication fork or direct damage to preformed DNA (Drake, 1974).

Treatments which specifically block progression of the replication fork (nalidixic acid, thymine starvation) induce DNA degradation in a retrograde manner from the growing point (Ramareddy \& Reiter, 1969; Reiter \& Ramareddy, 1970). This is in contrast to MEVinduced DNA degradation which was random with respect to the growing point. In each of two parallel cultures of strain $\mathrm{L} 699$, one prelabelled with $\left[{ }^{3} \mathrm{H}\right]$ thymidine for about a generation and then chased and the other pulse-labelled just before treatment, degradation started within the first Io to $20 \mathrm{~min}$ after addition of the drug (Fig. 6). The rate of increase in radioactivity in the TCA-soluble fraction was similar in the two cultures; however, the 


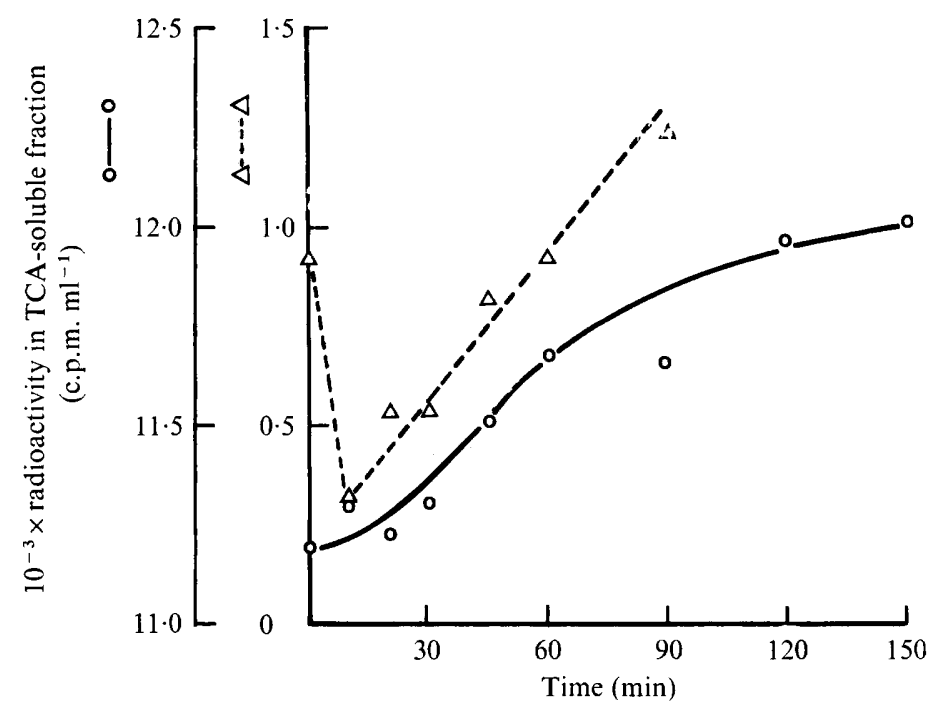

Fig. 6. Degradation of newly synthesized and older DNA by MEV treatment of $E$. coli. Cultures of strain L699 (thy) were labelled with $\left[{ }^{3} \mathrm{H}\right]$ thymidine either for $30 \mathrm{~min}$ followed by chasing for I05 min before treatment with $0.4 \mathrm{mM}-\mathrm{MEV}(\mathrm{O})$, or for Io min just before treatment with $0.4 \mathrm{mM}$ $\operatorname{MEV}(\triangle)$. At the time of drug addition (time 0 ), $E_{590}$ was 0.5 .

observation that radioactivity in the TCA-soluble fraction in the pulse-labelled culture decreased during the first 10 min of treatment precluded a precise estimate of the rate of degradation. This residual incorporation indicates only that the chase (addition of unlabelled thymidine at time zero) was not immediately effective, probably because a considerable fraction of the unincorporated $\left[{ }^{3} \mathrm{H}\right]$ thymidine was already in the nucleotide pool.

Thus MEV action appeared to be independent of replication. The observation that MEV was bactericidal and induced DNA turnover (unpublished data) and prophage $\lambda$ (Fig. 3) in non-replicating bacteria, treated in buffer, is consistent with this hypothesis.

\section{Properties of DNA from treated bacteria}

The observed action of MEV at a distance from the replication fork (Fig. 6), the hypersensitivity of the $u v r A$ strain (Fig. 2) and the almost complete dependence of MEV-induced DNA turnover on an intact $u v r A$ function (Fig. $5 b$ ) suggested that MEV action produced mainly endonuclease-sensitive lesions, rather than single-strand breaks. The presence of a rapidly-renaturing (cross-linked) component in the DNA of MEV-treated bacteria confirmed the existence of primary lesions other than breaks.

Recovery of DNA was progressively reduced as bacteria were treated with increasing concentrations of MEV. When strain L665 (uvrA) was treated for Io min with $0.4 \mathrm{~mm}$ MEV, it yielded about $15 \%$ as much DNA as did an equal number of untreated bacteria, and when treated with $0.8 \mathrm{mM}-\mathrm{MEV}$ it yielded only I \% as much. When strain $\mathrm{L} 694$ was treated with $0.33 \mathrm{mM}-\mathrm{MEV}$ for $\mathrm{I} 5 \mathrm{~min}$ it yielded $65 \%$ as much DNA as the untreated control, whilst mitomycin C-treated $\left(8 \mu \mathrm{g} \mathrm{ml}^{-1}\right)$ bacteria yielded $30 \%$.

In $\mathrm{CsCl}$ gradients, heat-denatured DNA from untreated bacteria of strain L665 (Fig. 7, trace $a$ ) and from bacteria of the same strain treated for Io min with $0 \cdot 1 \mathrm{mM}-\mathrm{MEV}(b)$ showed a single band. A light shoulder appeared on treatment with $0.2 \mathrm{mM}-\mathrm{MEV}(c)$ and a discrete light peak on treatment with $0.4 \mathrm{mM}-\mathrm{MEV}(d)$. In another experiment, the wild-type strain 


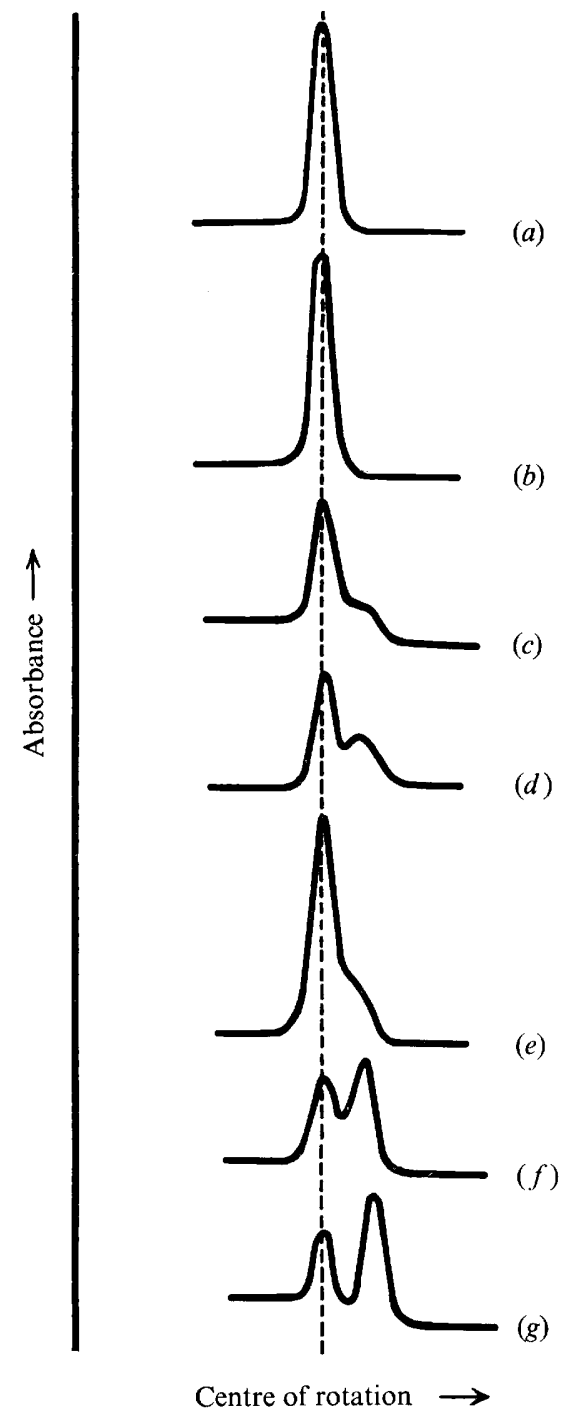

Fig. 7. $\mathrm{CsCl}$ gradients of denatured DNA from MEV-treated $E$. coli. Denatured DNA from strain L665 was (a) untreated, or treated for $10 \mathrm{~min}$ with MEV at (mM): (b) $0 \cdot 1,(c) 0 \cdot 2,(d) 0.4$. Strain L694 was treated for 15 min with $(e) 0.33$ mM-MEV or $(f) 8 \mu \mathrm{g}$ mitomycin $\mathrm{C} \mathrm{ml}^{-1} ;(g)$ mixture of native and denatured DNA from untreated strain L665. DNA of strain L665 was extracted by the phenol method and that of strain L694 by the method of Marmur (196I).

L694 was exposed for $\mathrm{I} 5 \mathrm{~min}$ to $0.33 \mathrm{mM}-\mathrm{MEV}$ or to $8 \mu \mathrm{g}$ mitomycin $\mathrm{C} \mathrm{ml}^{-1}$. Denatured DNA from the MEV-treated bacteria showed a light shoulder (Fig. 7, trace $e$ ) while two discrete peaks were seen in DNA from mitomycin C-treated bacteria $(f)$. Trace $(g)$ is of a gradient containing both native and denatured DNA from untreated strain $\mathrm{L} 665$.

While damage to DNA appears to be the cause of the bactericidal effect of MEV, we cannot say whether cross-links represent the major type of damage. A large fraction of the bacterial DNA was lost during purification from treated cells even in the $u v r A$ strain; some of this loss might have been due to the cross-linking of DNA to proteins (Moseley, 1968). The mechanism by which a molecule such as MEV might induce cross-links is not imme- 
diately obvious. Our studies of MEV (Goldstein et al., 1977) and work on other nitroheterocyclic drugs (McCalla et al., 1970; Ings et al., 1974) indicate that reactive compounds are evolved, within sensitive micro-organisms, by reduction of the nitro-drugs to their nitroso- and hydroxylamino-derivatives. Such reactive compounds might induce crosslinking indirectly (Fishbein, Flamm \& Falk, 1970; Bautz Freese et al., 1967). On the other hand, we have observed incorporation of ${ }^{14} \mathrm{C}$-labelled MEV metabolites into the cold TCA-precipitable fraction of treated bacteria (Goldstein et al., 1977) and another nitroimidazole, metronidazole, reportedly bound to DNA and proteins in Trichomonas vaginalis on metabolic activation (Ings et al., 1974). In the case of MEV, it is possible that oxidation of the vinyl moiety to the epoxide could provide a second reactive site on the molecule, allowing it to bridge two DNA strands (a suggestion made by M. Calvin).

We would like to thank Professor M. Calvin and Drs S. Riva and G. Pelizza for helpful discussions, Professor T. Tenconi and Dr E. Ginelli for the use of their equipment, Mr A. Morrone for technical assistance with the analytical ultracentrifuge and, in particular, Dr R. Vidal-Plana, who became actively involved in the last phase of this work.

\section{REFERENCES}

AdAMs, M. H. (1959). Bacteriophages. New York: Interscience (Wiley).

Austin, S. J., Tittawella, I. P. B., Hayward, R. S. \& Scaife, J. G. (I971). Amber mutations of Escherichia coli RNA polymerase. Nature New Biology 232, I 33-1 36.

Bautz Freese, E., Gerson, J., TAber, H., Rhaese, H. J. \& Freese, E. (1967). Inactivating DNA alterations induced by peroxides and peroxide-producing agents. Mutation Research 4, 5I 7-53I.

Braun, A. \& Grossman, L. (1974). An endonuclease from Escherichia coli that acts preferentially on UVirradiated DNA and is absent from the $u v r A$ and $u v r B$ mutants. Proceedings of the National Academy of Sciences of the United States of America $7 \mathbf{1}, 1838-1842$.

Cavalleri, B., BallotTa, R. \& Lancini, G. C. (1972). Synthesis of I-alkyl-2-nitroimidazole-5-carboxaldehydes. Journal of Heterocyclic Chemistry 9, 979-984.

Cavalleri, B., Ballotta, R., ARIoli, V. \& Lancini, G. C. (1973). New 5-substituted I-alkyl-2-nitroimidazoles. Journal of Medicinal Chemistry $\mathbf{1 5}, 557-560$.

Clark, A. J., Chamberlin, M., Boyce, R. P. \& Howard-Flanders, P. (1966). Abnormal metabolic response to ultraviolet light of a recombination deficient mutant of Escherichia coli KI 2. Journal of Molecular Biology r9, 442-454.

DANN, O. \& MöLLER, E. F. (1947). Bakteriostatisch wirkende Nitro-Verbindungen des Thiophens und Furans. Chemische Berichte 80, 23-36.

Davis, B. D. \& Mingioli, E. S. (I950). Mutants of Escherichia coli requiring methionine or vitamin BI2. Journal of Bacteriology 60, 17-28.

Dodd, M. C. \& Stillman, W. B. (1944). The in vitro bacteriostatic action of some simple furan derivatives. Journal of Pharmacology and Experimental Therapeutics 82, I I-I 8.

Drake, J. W. (1974). Mutagenesis in bacteriophage T4: direct or indirect? In Molecular and Environmental Aspects of Mutagenesis, pp. 63-72. Edited by L. Prakash, F. Sherman, M. W. Miller, C. W. Lawrence and $\mathrm{H}$. W. Taber. Springfield, Illinois: Charles C. Thomas.

Endo, H., Ishizawa, M., KamiYa, T. \& Kuwano, M. (1963). A nitrofuran derivative, a new inducing agent for phage development in lysogenic Escherichia coli. Biochimica et biophysica acta 68, 502-505.

FishbeIN, L., Flamm, W. G. \& FALK, H. L. (1970). Chemical Mutagens, Environmental Effects on Biological Systemis. New York: Academic Press.

Goldstein, B. P., Vidal-Plana, R. R., Cavalleri, B., Zerilli, L., Carniti, G. \& Silvestri, L. G. (I977). The mechanism of action of nitro-heterocyclic antimicrobial drugs. Metabolic activation by microorganisms. Journal of General Microbiology 100, 283-298.

INGS, R. M. J., McFadzean, J. A. \& ORMerod, W. E. (1974). The mode of action of metronidazole in Trichomonas vaginalis and other microorganisms. Biochemical Pharmacology 23, 142 I-1429.

IYER, V. N. \& SzYBALSKI, W. (1963). A molecular mechanism of mitomycin action: linking of complementary DNA strands. Proceedings of the National Academy of Sciences of the United States of America 50, 355-362.

Kirby, E. P., RufF, W. L. \& Goldthwatt, D. A. (1972). Cell division and prophage induction in Escherichia coli: Effects of pantoyl lactone and various furan derivatives. Journal of Bacteriology rrr, 447-453. 
Lancini, G. C. \& Lazzari, E. (1965). The synthesis of azomycin. Experientia 21, I-2.

MAHLER, H. R. \& Cordes, E. H. (1966). Biological Chemistry. New York: Harper \& Row.

MARMUR, J. (196I). A procedure for the isolation of deoxyribonucleic acid from microorganisms. Journal of Molecular Biology 3, 208-2 18.

MCCalla, D. R., Reuvers, A. \& KaISER, C. (I970). Mode of action of nitrofurazone. Journal of Bacteriology I04, I I 26-I I 34 .

Miller, J. H. (1972). Experiments in Molecular Genetics. Cold Spring Harbor: Cold Spring Harbor Laboratory.

Moseley, B. E. B. (1968). The repair of damaged DNA in irradiated bacteria. Advances in Microbial Physiology 2, 173-194.

Paul, H. E. \& Paul, M. F. (1964). The nitrofurans-chemotherapeutic properties. Experimental Chemotherapy 2, 307-370.

RAmAREDDY, G. \& Reiter, H. (1969). Specific loss of newly replicated deoxyribonucleic acid in nalidixic acid-treated Bacillus subtilis $\mathrm{I} 68$. Journal of Bacteriology roo, 724-729.

ReITER, H. \& RAMAREDDY, G. (1970). Loss of DNA behind the growing point of thymine-starved Bacillus subtilis $\mathrm{I} 68$. Journal of Molecular Biology 50, 533-548.

Saeki, T., Umezawa, H., Tokieda-Fujishige, T. \& Hori, M. (I974). Biological effects of azomycin (2-nitroimidazole): Inhibition of ribonucleoside reductase. Journal of Antibiotics 27, 225-227.

Saito, H. \& MiURA, K. (I963). Preparation of transforming deoxyribonucleic acid by phenol treatment. Biochimica et biophysica acta 72, 619-629.

TU, Y. \& MCCALLA, D. R. (I975). Effect of activated nitrofurans on DNA. Biochimica et biophysica acta 402, 142-I 49.

Voogd, C. E., VAN der Stel, J. J. \& Jacobs, J. J. A. A. A. (1974). The mutagenic action of nitroimidazoles. I. Metronidazole, nimorazole, dimetridazole and ronidazole. Mutation Research 26, 483-490.

Voogd, C. E., VAN Der Stel, J. J. \& JACobs, J. J. A. A. A. (1975). The mutagenic action of nitroimidazoles. II. Effects of 2-nitroimidazoles. Mutation Research 31, I49-152.

WITKIN, E. M. (I974). Thermal enhancement of ultraviolet mutability in a tif-1 uvrA derivative of Escherichia coli $\mathrm{B} / \mathrm{r}$ : evidence that ultraviolet mutagenesis depends upon an inducible function. Proceedings of the National Academy of Sciences of the United States of America 71, 1930-1934.

Yahagi, T., Nagao, M., Kazuko, H., Matsushima, T., Sugimura, T. \& Bryan, G. T. (I974). Relationships between the carcinogenic and mutagenic or DNA-modifying effects of nitrofuran derivatives including 2-(2-furyl)-3-(5-nitro-2-furyl)acrylamide, a food additive. Cancer Research 34, 2266-2273.

ZAMPIERI, A. \& Greenberg, J. (1964). Nitrofurazone as a mutagen in Escherichia coli. Biochemical and Biophysical Research Communications 14, I72-176. 